\title{
Changes in Vegetation Structure through Time in a Restored Tallgrass Prairie Ecosystem and Implications for Avian Diversity and Community Composition
}

\author{
Brian F.M. Olechnowski, Diane M. Debinski, Pauline Drobney, Karen Viste-Sparkman and \\ William T. Reed
}

\begin{abstract}
Grassland birds are one of the most endangered taxa in temperate North America. Because many species declines have been linked to habitat fragmentation and loss, large-scale prairie restoration projects have the potential to provide critical habitat for these declining species. We examined how the structure of restored grassland habitat changes through time and how diversity and community composition of grassland birds respond to these changes. Our study was completed at Neal Smith National Wildlife Refuge, a large-scale prairie restoration in central lowa. Vegetation composition and structure were measured at 42 restored grassland plots throughout the refuge in 2007. Birds were surveyed at these locations from 1994 to 2007. Survey points were sorted into five categories (out of crop rotation for 1, 2, 3, 4-6, and >6y). In the initial phases of restoration, species such as horned larks, red-winged blackbirds, and killdeer were abundant. Other species such as common yellowthroats and dickcissels were more common in established restored points. Henslow's sparrows appeared only at survey points that were out of crop rotation for more than 6 years. Diversity peaked in survey points that were 2-3 years out of crop rotation and points that were more than 6 years out of rotation. Community composition shifted through the chronosequence of prairie plantings. Changes in diversity and shifts in community composition can be explained by changes in vegetative structure. Our results suggest that managing for a variety of restored prairie stages will best maintain the highest levels of avian diversity and abundance.
\end{abstract}

Keywords: avian, community composition, diversity, prairie stages, temporal

Therser emperate grasslands are one of the world's most endangered ecosystems (Van Dyke et al. 2004). In North America alone, 99 percent of the original tallgrass prairie has been destroyed or modified, primarily for agricultural purposes (Lunt 2003). A number of studies have examined the impacts of management practices on restored tallgrass prairies in terms of the presence and nesting success of the grassland birds (Fletcher and Koford 2002, Van Dyke et al. 2004). Birds are a useful indicator taxon in

Ecological Restoration Vol. 27, No. 4, 2009 ISSN 1522-4740 E-ISSN 1543-4079 (C)2009 by the Board of Regents of the University of Wisconsin System. conservation biology; their status often reflects the overall health of the ecosystem (Taper et al. 1995). Grassland birds are also declining faster than any other groups of avian species in temperate North America (Peterjohn and Sauer 1993, Knopf 1994). For example, Henslow's sparrow (Ammodramus henslowii), grasshopper sparrow (A. savannarum), and bobolink (Dolichonyx oryzivorus) are just a few grassland specialist species that have faced significant population declines in the past several decades (Vickery et al. 1999, Sauer et al. 2004).

A number of studies have focused on the effects of specific restoration management practices (such as burning, grazing, and mowing) on grassland bird communities (Van Dyke et al. 2004, Fuhlendorf et al. 2006, Powell 2006). However, few studies have examined how the variation in vegetation structure of tallgrass prairies as restoration progresses influences bird diversity and community structure (in addition to management practices that have been more thoroughly examined, such as mowing, burning, and grazing) (Winter et al. 2005). The structure of vegetation in managed grassland systems can vary over time on the same site (Winter et al. 2005). Thus managers need to understand how changes in habitat structure of restored tallgrass prairies affect bird communities. 
The central objective of our study is to examine how specific grassland bird species respond to changes in vegetation structure over time since individual prairie restorations have been removed from crop rotation. The prairie plantings are all part of a larger restoration complex that makes up the Neal Smith National Wildlife Refuge in central Iowa. We also evaluate shifts in avian community composition through a chronosequence of prairie plantings and changes in vegetation due to management of these restored tallgrass prairies. Other studies have examined similar questions related to changes in bird diversity and relative abundance over time, but on smaller scales, primarily in grassland plantings that are part of the Conservation Reserve Program (Millenbach et al. 1996, McCoy et al. 2001). However, this is a novel study because we address these questions over both large spatial and long temporal scales (approximately 2,300 ha examined over a decade).

We expected to see the greatest diversity of bird species in restored areas that were at least three years old. We assumed that this amount of time would allow the vegetation structure to increase in complexity and provide space for a variety of bird species to forage and reproduce. A number of other studies have demonstrated that avian diversity increases in grassland systems with increased levels of vertical and horizontal vegetation structure (Hilden 1965, Cody 1968, Wiens 1969, Zimmerman 1971). Fuhlendorf and others (2006) demonstrated that grass cover, litter cover, and vegetation height increased in tallgrass prairies over time after a disturbance such as patch-burn-grazing. These changes in environmental variables indicated an overall increase in complexity of vegetation structure and promoted increased avian species diversity.

We further hypothesized that grassland bird species most sensitive to changes in vegetation structure (grassland specialists) would show the most pronounced shifts in abundance through time. These specialists include Henslow's sparrows and dickcissels (Spiza americana) (Cully and Michaels 2000, Walk and Warner 2000). We expected that increased complexity in the vegetative structure could increase preferred microhabitats for nesting and foraging for a number of other species (bobolink, grasshopper sparrow, and eastern meadowlark [Sturnella magna]). Martin (1998, 2001) discusses how imperative these microhabitats are for avian species during the breeding season. Finally, we expected bird community composition to shift through time as the plantings became better established (more than 3 years). For example, as cropland is converted to herbaceous grassland habitat, early successional grassland species that use these agricultural fields (horned lark [Eremophila alpestris], vesper sparrow [Pooecetes gramineus], and killdeer [Charadrius vociferus]) would become less abundant, whereas tallgrass prairie specialists (bobolinks, eastern meadowlarks, and Henslow's sparrows) would become more abundant in subsequent years (Thomas 1999, B. Giesler, Neal Smith NWR, pers. comm.).

\section{Methods}

Study Area-We conducted our work on a large-scale restoration project, Neal Smith National Wildlife Refuge (NSNWR) in Prairie City, Iowa (approximately 2,300 ha). The refuge was established in 1990 and prairie plantings began in 1992 to restore an area of Iowa that was historically prairie and savanna (USFWS 1992). At the time of acquisition, there were 565 ha of relict natural communities within the refuge boundaries, including 293 ha of highly fragmented and disturbed prairie remnants, 182 ha of overgrown oak savanna and wooded gullies, and 89 ha of relict riparian areas (Roelle and Hamilton 1993, Thomas 1999). The total area under restoration has increased since 1992 , and an average of 200-250 ha of new prairie plantings are planned each year (beyond 2008). In 1992, a total of 87 ha of new grassland had been restored, and approximately 3,600 ha as of 1998. The major goals of the refuge include restoring native tallgrass prairie, wetland, and savanna habitats and performing research to guide the recovery of these systems (Roelle and Hamilton 1993, Drobney 1994). This long-term project has allowed us to examine the structure of the vegetation and composition of avian communities at a number of large-scale prairie plantings within the refuge that were established at different times over the last 13 years.

Sampling Sites and Chronosequence Stages-We took a chronoseries approach to this study (sampling prairie plantings at different stages of restoration over time). From 1994 to 2007, 42 survey points in restored grasslands were surveyed for birds. At each site, a center point was located for avian surveys. These points were separated by at least $200 \mathrm{~m}$ (as used in Thomas 1999). The minimum patch size of the fields in which we established these points was 25 ha. There was no established minimum distance from the edge of the refuge, and some prairie plantings are bordered by roads and woody areas. Edge is difficult to control for in this study because the interior of NSNWR includes patches of woodland and scattered agricultural fields. We examined the avian survey data in terms of how long each survey point had been out of crop rotation and planted with native prairie species since 1994. The five chronosequence stages we used are first-year restoration $(n=28)$, second-year restoration $(n=20)$, third-year restoration $(n=$ $20)$, restored for four to six years $(n=$ 24), and restored for longer than six years $(n=30)$, since in our experience few changes in vegetation and avian communities occur after this length of time. Although each survey point was sampled annually once established, we analyzed the data from a single randomly chosen year for the later chronosequence stages ( $4-6 \mathrm{y}$ and $>6 \mathrm{y}$ ) so that each survey point was represented no more than once per stage. 
A variety of prairie management practices are used at NSNWR, including burning and mowing. While these practices may pose a concern in pinpointing the main effects that are driving our diversity responses, burning and mowing are controlled for based on how long the site has been out of cropland (P.M. Drobney, pers. comm.). Mowing is typically done the first year after a site is planted. Partial burns then typically follow every other year. There are occasional exceptions, especially when invasive species are found at a site, and localized management such as spraying may occur on that site regardless of how long it has been out of crop rotation. Refuge staff examine plantings annually to assess the need for burning, and nonnative species cover is often the driving factor determining when fire is recommended on a site.

Measurement of Habitat StructureVegetation was measured at each of the 42 restored grassland survey points during late May and June 2007. Data describing the habitat structure were collected at five locations at each survey point: one at the center of the site and one at each cardinal direction $30 \mathrm{~m}$ from the center point of the site. The following data were collected at each location: litter depth; composition of the litter (plant, rock, soil, or woody material); composition of the vegetation (woody, forb, or grass); and maximum height of the vegetation and its vertical density, measured as percent obscurity using a Robel pole (Robel et al. 1970). The $125 \mathrm{~cm}$ pole was partitioned into $10 \mathrm{~cm}$ segments; each considered a "zone." The percent obscurity was estimated to the lower limit of the first zone visible from a distance of $1 \mathrm{~m}(0 \mathrm{~cm}=0 \%, 1-20 \mathrm{~cm}$ $=1 \%,>20-40 \mathrm{~cm}=20 \%,>40-60$ $\mathrm{cm}=40 \%,>60-80 \mathrm{~cm}=60 \%$, and $>80-100 \mathrm{~cm}=80 \%)$. A measurement of $100 \%$ was recorded when the pole was fully obscured by vegetation.

Avian Surveys-Birds were surveyed once per season from 1994 to 2007 at the center point of each site. Sampling took place during the breeding season (late May-June). Individuals were surveyed between 5:30 A.M. and 10:30 A.M. using ten-minute point counts in circular plots (measured from the center point of each site). During a survey, each bird seen or heard within the $50 \mathrm{~m}$ radius was recorded, and its location and distance from the observer were mapped. Flyovers were not included in the analysis because we were interested in only those individuals that showed evidence of actually utilizing the habitat for foraging and reproduction. We examined how the abundance of 12 grassland songbird species changed through the chronosequence of prairie plantings; all songbird species were included in an overall diversity analysis. The seven grassland species (dickcissel, grasshopper sparrow, horned lark, killdeer, bobolink, vesper sparrow and Henslow's sparrow) and five generalist species (red-winged blackbird [Agelaius phoeniceus], American goldfinch [Carduelis tristis], common yellowthroat [Geothlypis trichas], song sparrow [Melospiza melodia], and American robin [Turdus migratorius]) were chosen a priori based on expected abundance patterns for the specieslevel analysis.

Statistical Analyses-All statistical analyses were performed using S-Plus (vers. 7.0, Insightful, Seattle WA) and PC-ORD (vers. 4.0, MjM Software Design, Gleneden Beach OR). Repeated measures one-way ANOVA was used to examine the differences in avian species richness and abundance through the chronosequence of prairie plantings and to assess the differences in prairie habitat structure as the restorations proceeded through time. The Tukey-Kramer procedure was used as a follow-up analysis to test for differences in avian abundance through prairie stages (for each species analyzed) and for specific significant differences in habitat variables through the restoration categories. Multiple comparisons of species were corrected for using a sequential Bonferroni test (Holland and Copenhaver 1987). Both Shannon's Index and Simpson's
Index were used to examine avian alpha diversity through the various stages of prairie restoration (Shannon and Weaver 1949, Simpson 1949). It is useful to consider both of these because Shannon's Index is sensitive to changes in rare species and Simpson's Index is sensitive to changes in the most abundant species (Magurran 2004). Differences in avian community composition across the chronosequence of prairie plantings were evaluated using both Sorensen's Index and the Bray-Curtis Index (Sørensen 1948, Bray and Curtis 1957). The former is based on relative presence/ absence data, and the latter accounts for relative abundances of individuals of different species.

Avian community compositions through the chronosequence of prairie plantings were also assessed using a multirandom permutation procedure (MRPP) employing the Bray-Curtis distance measures. This is a nonparametric procedure for testing the hypothesis of no difference between two or more groups (McCune and Mefford 1999). The MRPP has the advantage of not requiring the assumptions of multivariate normality and homogeneity of variances (McCune and Mefford 1999). The statistic (A) is the chance-corrected within-group agreement:

$$
A=1-\frac{\left(\begin{array}{l}
\text { observed difference in the } \\
\text { distances between values in } \\
\text { the community matrix }
\end{array}\right)}{\left(\begin{array}{l}
\text { expected differences in the } \\
\text { distances between values in } \\
\text { the community matrix }
\end{array}\right)}
$$

When all items are identical within groups, then $A=1$, the highest possible value. If heterogeneity within groups equals that expected by chance, then $A=0$. Finally, if there is less agreement within groups than expected by chance, then $A<0$. Values of $A<0.1$ are often observed with community ecology data, even when the observed distances between values in the community matrix differ significantly 
Table 1. Mean ( \pm SE) annual abundance of 12 songbird species inhabiting different stages of tallgrass prairie restorations (recorded as years out of crop rotation) at Neal Smith National Wildlife Refuge in lowa. Data were pooled from 1994 through 2007 and ANOVA was used to test for differences, followed by Tukey-Kramer analysis. Species that were significantly different across restoration stages are indicated by different letters.

\begin{tabular}{|c|c|c|c|c|c|c|c|}
\hline \multirow[b]{2}{*}{ Species } & \multicolumn{7}{|c|}{ Annual Abundance } \\
\hline & 1 y $(n=28)$ & 2 y $(n=20)$ & 3 y $(n=20)$ & $4-6$ y $(n=24)$ & $6+y(n=30)$ & $F$ & $p$ \\
\hline $\begin{array}{l}\text { American goldfinch } \\
\text { (Carduelis tristis) }\end{array}$ & $0.61(0.36)$ & $1.20(0.43)$ & $1.00(0.43)$ & $1.25(0.39)$ & $1.23(0.36)$ & 0.50 & 0.7327 \\
\hline $\begin{array}{l}\text { American robin } \\
\text { (Turdus migratorius) }\end{array}$ & $0.11(0.04)$ & $0.00(0.00)$ & $0.10(0.05)$ & $0.04(0.05)$ & $0.03(0.04)$ & 0.89 & 0.4725 \\
\hline $\begin{array}{l}\text { Bobolink } \\
\text { (Dolichonyx oryzivorus) }\end{array}$ & $0.07(0.04)$ & $0.00(0.00)$ & $0.00(0.00)$ & $0.00(0.00)$ & $0.07(0.04)$ & 0.84 & 0.5658 \\
\hline $\begin{array}{l}\text { Common yellowthroat } \\
\text { (Geothlypis trichas) }\end{array}$ & $0.10(0.17) b$ & $0.75(0.20) a b$ & $1.16(0.20) \mathrm{a}$ & $0.58(0.18) a b$ & $1.03(0.16) \mathrm{a}$ & 5.49 & 0.0004 \\
\hline $\begin{array}{l}\text { Dickcissel } \\
\text { (Spiza americana) }\end{array}$ & $0.55(0.21) b$ & $1.55(0.25) \mathrm{a}$ & $1.40(0.25) \mathrm{ab}$ & $1.04(0.23) a b$ & $1.03(0.21) a b$ & 3.13 & 0.0173 \\
\hline $\begin{array}{l}\text { Grasshopper sparrow } \\
\text { (Ammodramus savannarum) }\end{array}$ & $0.46(0.16)$ & $0.85(0.18)$ & $0.50(0.19)$ & $0.33(0.17)$ & $0.33(0.16)$ & 1.26 & 0.2881 \\
\hline $\begin{array}{l}\text { Henslow's sparrow } \\
\text { (Ammodramus henslowii) }\end{array}$ & $0.00(0.00) b$ & $0.00(0.00) b$ & $0.00(0.00) b$ & $0.00(0.00) b$ & $0.43(0.07) a$ & 7.15 & $<0.0001$ \\
\hline $\begin{array}{l}\text { Horned lark } \\
\text { (Eremophila alpestris) }\end{array}$ & $0.36(0.06) a$ & $0.00(0.00) b$ & $0.00(0.00) b$ & $0.00(0.00) b$ & $0.00(0.00) b$ & 7.26 & $<0.0001$ \\
\hline $\begin{array}{l}\text { Killdeer } \\
\text { (Charadrius vociferous) }\end{array}$ & $0.78(0.11) a$ & $0.10(0.13) b$ & $0.00(0.00) b$ & $0.00(0.00) b$ & $0.00(0.00) b$ & 9.90 & $<0.0001$ \\
\hline $\begin{array}{l}\text { Red-winged blackbird } \\
\text { (Agelaius phoeniceus) }\end{array}$ & $1.53(0.39) b$ & $3.40(0.47) a$ & $2.55(0.47) a b$ & $2.08(0.43) a b$ & $1.73(0.39) a b$ & 2.82 & 0.0283 \\
\hline $\begin{array}{l}\text { Song sparrow } \\
\text { (Melospiza melodia) }\end{array}$ & $0.14(0.07)$ & $0.20(0.08)$ & $0.25(0.09)$ & $0.08(0.08)$ & $0.10(0.07)$ & 0.67 & 0.6150 \\
\hline $\begin{array}{l}\text { Vesper sparrow } \\
\text { (Pooecetes gramineus) }\end{array}$ & $0.32(0.07) a$ & $0.05(0.08) a b$ & $0.05(0.08) a b$ & $0.00(0.00) b$ & $0.00(0.00) b$ & 4.16 & 0.0076 \\
\hline
\end{tabular}

from the expected (this could occur with sample sizes as large as $n=200$ ) (McCune and Mefford 1999).

\section{Results}

\section{Avian Trends through a Chronosequence of Prairie Planting}

Seven of the 12 songbird species examined showed significant differences in levels of abundance through the chronosequence of prairie plantings (Table 1). Horned larks appeared only in survey points that were one year out of crop rotation, killdeer appeared only in survey points that were one or two years out of crop rotation, and vesper sparrows were absent from survey points that were more than three years out of crop rotation. Both red-winged blackbirds and dickcissels peaked in abundance in survey points two or three years out of crop rotation.
The highest levels of common yellowthroats occurred in survey points that were either three or more than 6 years out of rotation.

Differences over time in both avian richness and avian abundance were significant (Table 2). Richness and abundance levels exhibited a bimodal response over time and were greatest in survey points that were two to three or more than six years out of rotation. Shannon's Index and Simpson's Index, both of which measure alpha diversity, were also significantly different through the chronosequence of prairie plantings on the refuge. They had the greatest values in survey points that were two to three years and more than six years out of crop rotation.

A total of 40 bird species were observed across the 42 surveyed points. Avian community composition changed significantly through the chronosequence of prairie plantings (Table 3). While all of the similarity measurements between restoration stages were low $(A<0.05)$, the avian community composition in survey points one year out of crop rotation was significantly dissimilar to that of all other stages, as was the avian community composition in plantings older than six years (Table 4).

\section{Restored Prairie Habitat Structure through a Chronosequence of Prairie Plantings}

The percent cover of forbs and grass and density of the lower levels of vegetation changed significantly through the chronosequence of tallgrass prairie plantings (Figure 1a). Forb cover reached its maximum $(54.5 \%)$ in survey points that were three years out of crop rotation and its minimum $(21.3 \%)$ in points that were more than six years out of crop rotation. Grass cover reached its maximum $(78.7 \%)$ 
more than six years out of crop rotation and a minimum (15.0\%) one year out of crop rotation. Percent obscurity (vegetation density) of the lower levels of vegetation reached a maximum $(77.2 \%)$ in survey points more than six years out of crop rotation and a minimum $(0.6 \%)$ one year out of crop rotation. Average litter depth (Figure 1b) and average maximum vegetation height (Figure 1c) also changed significantly as tallgrass prairie plantings aged. Litter depth increased gradually as the plantings aged (from $0.20 \mathrm{~cm}$ to $7.58 \mathrm{~cm}$ ). The average maximum height of the vegetation was lowest in survey points one year out of crop rotation $(23.87 \mathrm{~cm})$. Survey points that were three to more than six years out of crop rotation had similar maximum vegetation heights.

\section{Discussion}

\section{Individual Species Trends and Habitat Changes through Prairie Restoration Stages}

Red-winged blackbird, dickcissel, common yellowthroat, horned lark, killdeer, vesper sparrow, and Henslow's sparrow all displayed significant changes in abundance through the chronosequence of tallgrass prairie plantings at NSNWR. Horned larks, killdeer, and vesper sparrows were highest in abundance in survey points that were one year out of crop rotation. These three species selectively use and nest in open, sparsely vegetated habitats (Herkert 1994, Best et al. 1995). The expansive areas of agricultural landscape in the state of Iowa have provided increased nesting opportunities for these species and have allowed them to sustain their populations in the central United States (Best et al. 1995). Low levels of litter and short vegetation, such as are found in our survey points one year out of crop rotation, appeal to horned larks, killdeer, and vesper sparrows. These species decreased in abundance in survey points that were two or more years out of crop rotation, as expected.

Table 2. A comparison of mean ( \pm SE) abundance, species richness, Shannon's Index, and Simpson's Index of birds inhabiting different stages of tallgrass prairie restorations (recorded as years out of crop rotation) at Neal Smith National Wildlife Refuge in lowa. Data were pooled from 1994 through 2007 and an ANOVA was used to test for differences.

\begin{tabular}{lllll}
\hline Stage $(\mathrm{y})$ & Richness & Abundance & Shannon & \multicolumn{1}{c}{ Simpson } \\
\hline $1(n=28)$ & $2.89(0.33)$ & $6.14(0.86)$ & $0.89(0.09)$ & $0.52(0.04)$ \\
$2(n=20)$ & $3.90(0.39)$ & $9.90(1.02)$ & $1.10(0.11)$ & $0.60(0.05)$ \\
$3(n=20)$ & $4.10(0.39)$ & $8.00(1.02)$ & $1.24(0.11)$ & $0.68(0.05)$ \\
$4-6(n=24)$ & $3.29(0.35)$ & $6.21(0.93)$ & $1.00(0.10)$ & $0.56(0.05)$ \\
$6+(n=30)$ & $4.57(0.27)$ & $7.90(0.71)$ & $1.38(0.08)$ & $0.69(0.04)$ \\
$F$ & 2.01 & 2.65 & 5.52 & 3.91 \\
$p$ & 0.0023 & 0.0367 & 0.0004 & 0.0051 \\
\hline
\end{tabular}

Table 3. Evaluating similarity in community composition of birds inhabiting different stages of tallgrass prairie restorations (recorded as years out of crop rotation) at Neal Smith National Wildlife Refuge in lowa using Sørensen's Index and the Bray-Curtis Index, reported as means ( \pm SE). Data were pooled from 1994 through 2007 and an ANOVA was used to test for differences.

\begin{tabular}{lcl}
\hline Stage $(\mathrm{y})$ & Sorensen & Bray-Curtis \\
\hline 1 vs. 2 & $0.27(0.25)$ & $0.27(0.05)$ \\
2 vs. 3 & $0.59(0.05)$ & $0.47(0.05)$ \\
3 vs. $4-6$ & $0.54(0.07)$ & $0.41(0.06)$ \\
$4-6$ vs. $6+$ & $0.41(0.07)$ & $0.34(0.07)$ \\
1 vs. $6+$ & $0.25(0.07)$ & $0.20(0.06)$ \\
$F$ & 6.83 & 3.89 \\
$p$ & $<0.0001$ & 0.0070 \\
\hline
\end{tabular}

Table 4. Pairwise comparisons of similarity of avian communities inhabiting different stages of tallgrass prairie restorations (recorded as years out of crop rotation) at Neal Smith National Wildlife Refuge in lowa using a multirandom permutation procedure (MRPP). The Bray-Curtis distance measure is used to quantify similarity $(A)$.

\begin{tabular}{lrr}
\hline Stage $(y)$ & $A$ & \multicolumn{1}{c}{$p$} \\
\hline 1 vs. 2 & 0.0365 & 0.0007 \\
1 vs. 3 & 0.0444 & $<0.0001$ \\
1 vs. $4-6$ & 0.0497 & $<0.0001$ \\
1 vs. $6+$ & 0.0491 & $<0.0001$ \\
2 vs. 3 & -0.0046 & 0.6761 \\
2 vs. 4 & 0.0022 & 0.3383 \\
2 vs. $6+$ & 0.0142 & 0.0277 \\
3 vs. $4-6$ & -0.0017 & 0.5350 \\
3 vs. $6+$ & 0.0089 & 0.0714 \\
$4-6$ vs. $6+$ & 0.0120 & 0.0318 \\
\hline
\end{tabular}

Red-winged blackbirds, common yellowthroats, and dickcissels increased in abundance in survey points two or more years out of crop rotation. Red-winged blackbirds and common yellowthroats are generally abundant throughout the refuge (Thomas 1999). They use a variety of habitats for nesting. However, they do require some habitat cover (Best et al. 1995), and their abundance was lower in survey points that were only one year out of crop rotation (short vegetation, very low vegetation density). Red-winged blackbirds decreased in abundance after more than two years out of rotation because they do not prefer grassy sites or deep litter depths (Scott et al. 

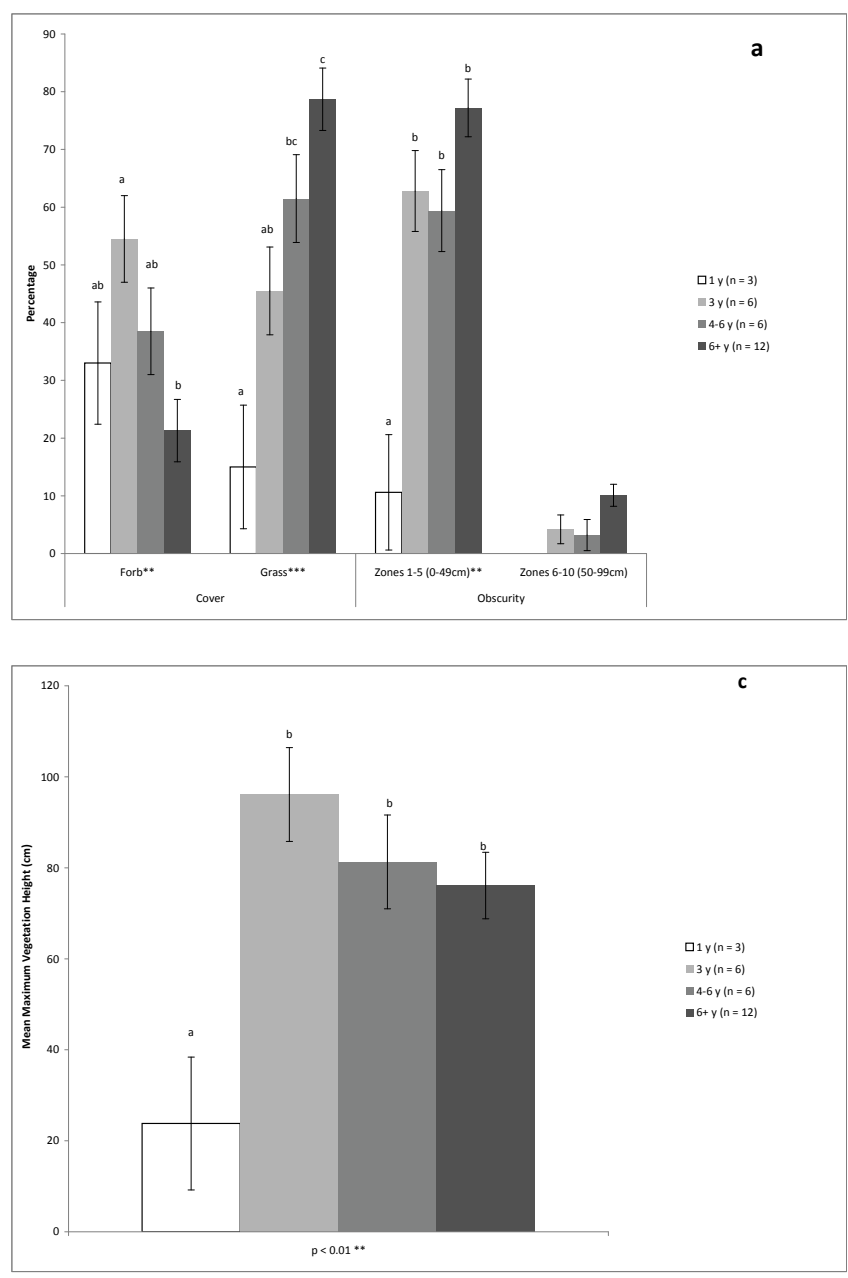

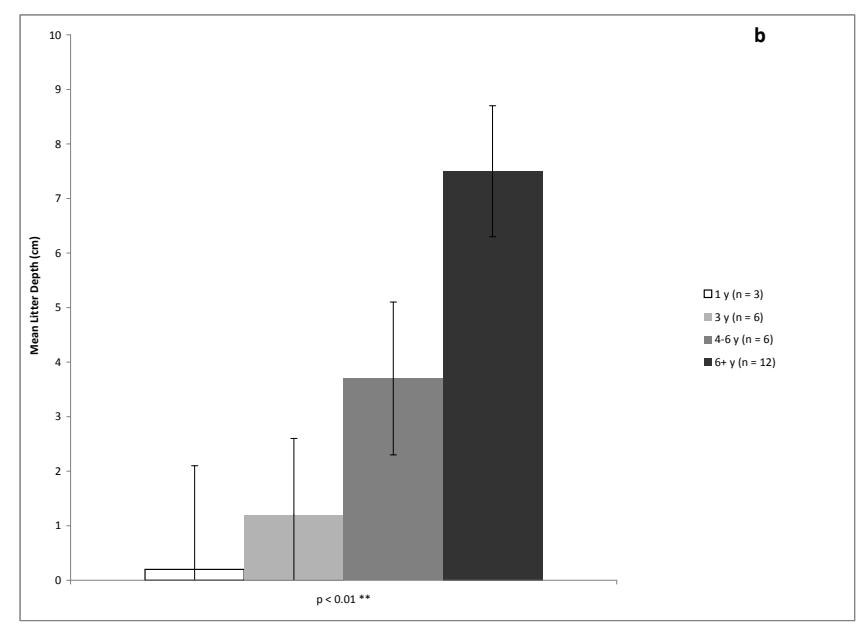

Figure 1. Change in vegetation composition and structure over time: a) average percent forb cover $(p=0.004)$, grass cover $(p<0.001)$, and obscurity (density) of the vegetation $(p<0.001)$; b) average litter depth $(p=0.006)$; and $c)$ average maximum vegetation height $(p=0.005)$ across different stages of tallgrass prairie restorations (recorded as years out of crop rotation) at Neal Smith National Wildlife Refuge measured in late-May and June 2007. Significantly different groups using TukeyKramer analysis are indicated by different letters.
2002). Dickcissels prefer intact prairie habitat (Thomas 1999, Powell 2006) and were more abundant in areas that were more than one year out of crop rotation. However, this species is less dependent than other grassland birds on litter depth for nesting, which may be why dickcissels declined in survey points that were three or more years out of crop rotation (Volkert 1992, Powell 2006). Litter depth increased in older prairie plantings, and this deeper litter layer may be more preferred by other species competing for these nesting sites. Finally, dickcissels may have declined in survey points more than three years out of crop rotation because they prefer opportunities to perch (Zimmerman 1971), and the decrease in forb cover at these points limits perching locations (Zimmerman 1971).

Henslow's sparrows were found only in survey points that were six or more years out of crop rotation. Henslow's sparrows require tall, dense vegetation (Zimmerman 1988, Culley and Michaels 2000). The maximum height of the vegetation becomes relatively tall (around $95 \mathrm{~cm}$ ) two years after a survey point has been out of crop rotation, and vegetation density was greatest in points more than six years out of crop rotation. Henslow's sparrows also rely on litter and standing dead vegetation for both nesting and foraging (Volkert 1992, Reinking et al. 2000, Powell 2006). In addition, they prefer high levels of grass cover (Scott et al. 2002). We saw the greatest average litter depth and grass cover in survey points more than six years out of crop rotation.

It was not surprising that we observed no significant differences in abundance of American robins and song sparrows through the various prairie stages because these species are habitat generalists and prefer a wide range of habitat structures.
While the difference for grasshopper sparrows was not significant, there is some indication that their abundance declines in sites that are more than two years out of crop rotation. This is expected because grasshopper sparrows are found in areas with shorter vegetation (Swengel 1996, Powell 2006). The sample size of grasshopper sparrows may also be relatively low because these birds prefer xeric habitats (Swengel 1996). Surprisingly, we found bobolinks in very low abundance throughout all survey points. Herkert (1994) determined that patch size was the most important predictor for the presence of bobolinks on grasslands. Perhaps the mosaic of habitats in the refuge is not favorable. Bobolinks avoid heavily wooded areas, and NSNWR has many wooded areas dispersed throughout the landscape (Best et al. 1995). In addition, edge effects, which can decrease effective grassland patch sizes to smaller than required for 
bobolinks to forage and nest, may also hinder bobolinks from being found in our survey points (Best et al. 1995).

\section{Patterns of Avian Diversity, Community Composition, and Habitat Change through Prairie Restoration Stages}

Alpha diversity (species richness and abundance) followed a bimodal distribution through the chronosequence of prairie plantings, with maximum diversity reached in survey points that were out of crop rotation for either two to three years or over six years. Millenbach and others (1996) found a similar bimodal pattern in avian diversity on grass-dominated CRP fields in Michigan. It has been well documented that avian diversity is highly correlated with the structural characteristics of the habitat (MacArthur and MacArthur 1961, Jackson 1992, Yamaura et al. 2006). The first maximum in alpha diversity is likely due to the transition of avian communities from a grassland just out of crop rotation to one that is two to three years out of crop rotation. Species such as killdeer and vesper sparrows, which specialize in newly planted prairie habitat, continued to be present in survey points two years out of crop rotation. At this time, we also observed greater abundances of species, such as dickcissels and common yellowthroats, that utilize more complex habitat structure. The maximum height and density of vegetation increased rapidly as the plantings matured from one to three years old. Grassland specialists rely on tall, grassy vegetation to nest and forage (Best et. al 1995, Thomas 1999, Powell 2006). The change in habitat structure between one and two years out of crop rotation also likely explains why we observed the largest change in avian community composition between these two time periods (as measured by both the Sorensen Index and the Bray-Curtis Index). The MRPP indicates that avian community composition was always significantly different between survey points one year out of rotation and all other points. Survey points one year out of rotation are mowed to help control invasive species, and this management contributes to the differences in vegetation structure and bird diversity that we observed between these points and points out of rotation for longer periods of time.

We observed a decline in diversity in survey points that were four to six years out of crop rotation. This may be due to the decline in forb cover in older prairie plantings. Dion and colleagues (2000) reported that grassland songbirds have greater nesting success in areas that have greater forb cover than grass cover. Nest predation by ground squirrels (Spermophilus spp.) and other small mammals increases in frequency in sites that have greater grass cover (Dion et al. 2000). This decreased nesting success could contribute to the decline in abundance of several bird species in survey points four to six years out of rotation. However, despite the decrease in forbs, we saw another peak in diversity in survey points more than six years out of crop rotation. Summerville and others (2007) found that older plantings (at least seven years old) of tallgrass prairie in central Iowa contained the highest level of Lepidoptera diversity. This increased food supply would benefit the songbirds nesting in these older restorations. In addition, the greater litter depth in survey points six or more years out of crop rotation especially benefits species such as Henslow's sparrow (more nest cover, preferred ground microhabitat) (Culley and Michaels 2000, Scott et al. 2002). Renfrew and Ribic (2001) also found greater abundance and richness of grassland birds in Wisconsin in sites with the deepest litter and highest vegetation densities. However, it is important to note that management practices differ at other locations and may result in differences in prairie succession.

\section{Implications for Practice}

- Avian diversity and relative abundance follows a bimodal response based on the age of the prairie plantings. We recommend that managers provide a variety of restored tallgrass prairie areas of different ages (varying vegetation structure and habitat features) to maintain simultaneously high avian diversity, abundance, and productivity.

- Prairie restorations older than six years harbor grassland-obligate species not found in younger restorations. Some of these species, such as Henslow's sparrow, are obligate specialist grassland species that have been in decline for a number of years. Restorations need to be managed to attract these specialists.

- Studies need to continue to examine the specific habitat variables driving grassland bird response patterns. This knowledge will guide managers and practitioners in how to attain maximum diversity in restored grasslands and how to attract specific grassland specialists to a restored area.

- The differences in songbird responses to vegetation composition versus vegetation structure have not been thoroughly been examined by ornithologists. We often assume that vegetation structure is more important, but vegetation composition may affect the prey base and thus may also play into the suite of predictor variables for grassland songbird communities.

\section{Acknowledgments}

We would like to thank the staff at Neal Smith National Wildlife Refuge for accommodating our field work. We would also like to thank Liessa Thomas, Brett Giesler, and the many other field technicians that have helped collect the bird survey data over the last decade. Funding was provided by the Iowa Department of National Resources (State Wildlife Grants Program administered by the U.S. Fish and Wildlife Service and the Small Diversity Grants Program SWG08/ T-1-R-18), Iowa Prairie Network, and the 
Iowa Academy of Sciences. Dianne Cook, faculty in statistics at Iowa State University, provided statistical consulting.

\section{References}

Best, L.B., K.E. Freemark, J.J. Dinsmore and M. Camp. 1995. A review and synthesis of habitat use by breeding birds in agricultural landscapes of Iowa. American Midland Naturalist 134:1-29.

Bray, J.R. and C.T. Curtis. 1957. An ordination of the upland forest communities of southern Wisconsin. Ecological Monographs 27:325-349.

Cody, M.L. 1968. On the methods of resource division in grassland bird communities. American Naturalist 102: 107-147.

Cully, J.F., Jr. and H.L. Michaels. 2000. Henslow's Sparrow habitat associations of Kansas tallgrass prairie. Wilson Bulletin 112:115-123.

Dion, N., K.A. Hobson and S. Lariviere. 2000. Interactive effects of vegetation and predators on the success of natural and simulated nests of grassland songbirds. Condor 102:629-634.

Drobney, P.M. 1994. Iowa prairie rebirth. Restoration \& Management Notes 12: 16-22.

Fletcher, R.J. and R.R. Koford. 2002. Habitat and landscape associations of breeding birds in native and restored grasslands. Journal of Wildlife Management 66:1011- 1022.

Fuhlendorf, S.D., W.C. Harrell, D.M. Engle, R.G. Hamilton, C.A. Davis and D.M. Leslie Jr. 2006. Should heterogeneity be the basis for conservation? Grassland bird response to fire and grazing. Ecological Applications 16: 1706-1716.

Herkert, J.R. 1994. The effects of habitat fragmentation on Midwestern grassland bird communities. Ecological Applications 4:461-471.

Hilden, O. 1965. Habitat selection in birds: A review. Annales Zoologici Fennici 23: 53-75.

Holland, B.S. and M.D. Copenhaver. 1987. An improved sequentially rejective Bonferroni test procedure. Biometrics 43:417-423.

Jackson, S.G. 1992. Relationships among birds, willows, and native ungulates in and around northern Yellowstone National Park. MS thesis, Utah State University.

Knopf, F.L. 1994. Avian assemblages on altered grasslands. Studies in Avian Biology 15:247-257.
Lunt, I.D. 2003. A protocol for integrated management, monitoring, and enhancement of degraded Themeda triandra grassland based on plantings of indicator species. Restoration Ecology 11: 223-230.

MacArthur, R.H. and J.W. MacArthur. 1961. On bird species diversity. Ecology 42:594-598.

Magurran, A.E. 2004. Measuring Biological Diversity. Oxford: Blackwell Publishing.

Martin, T.E. 1998. Are microhabitat preferences of coexisting species under selection and adaptive? Ecology 79:656-660. 2001. Abiotic v. biotic influences on habitat selection of coexisting species: Climate change impacts? Ecology 82:175-188.

McCoy, T.D., E.W. Kurzejeski, L.W. Burger Jr. and M.R. Ryan. 2001. Effects of conservation practice, mowing, and temporal changes on vegetation structure on CRP fields in northern Missouri. Wildlife Society Bulletin 29:979-987.

McCune, B. and M.J. Mefford. 1999. PC-ORD: Multivariate Analysis of Ecological Data, vers. 4.0. Gleneden Beach OR: MjM Software Design.

Millenbach, K.F., S.R. Winterstein, H. Campa III, L.T. Furrow and R.B. Minnis. 1996. Effects of Conservation Reserve Program field age on avian relative abundance, diversity, and productivity. Wilson Bulletin 108:760-770.

Peterjohn, B.G. and J.R. Sauer. 1993. North American breeding bird survey annual summary 1990-1991. Bird Populations $1: 1-15$.

Powell, A.F.L.A. 2006. Effects of prescribed burning and bison (Bos bison) grazing on breeding bird abundances in tallgrass prairie. Auk 1:183-197.

Reinking, D.L., D.A. Wiedenfeld, D.H. Wolfe and R.W. Rohrbaugh Jr. 2000. Distribution, habitat use, and nesting success of Henslow's Sparrow in Oklahoma. Prairie Naturalist 32:219-232.

Renfrew, R.B. and C.A. Ribic. 2001. Grassland birds associated with agricultural riparian practices in Southwestern Wisconsin. Journal of Range Management 54:546-552.

Robel, R.J., J.N. Briggs, A.D. Dayton and L.C. Hulbert. 1970. Relationships between visual obstruction measurements and weight of grassland vegetation. Journal of Range Management 23: 295-297.

Roelle, J.E. and D.B. Hamilton. 1993. Monitoring and research at Walnut Creek National Wildlife Refuge. Ft Collins CO: U.S. Fish \& Wildlife Service.
Sauer, J.R., J.E. Hines and J. Fallon. 2004 The North American breeding bird survey, results and analysis 1966-2003. Version 2004.1. Laurel MD: USGS Patuxent Wildlife Research Center.

Scott, P.E., T.L. DeVault, R.A. Bajema and S.L. Lima. 2002. Grassland vegetation and bird abundances on reclaimed Midwestern coal mines. Wildlife Society Bulletin 30:1006-1014.

Shannon, C.E. and W. Weaver.1949. The Mathematical Theory of Communication. Urbana: University of Illinois Press.

Simpson, E.H. 1949. Measurement of diversity. Nature 163:688.

Sørensen, T. 1948. A method of establishing groups of equal amplitude in plant sociology based on similarity of species content and its application to analyses of the vegetation on Danish commons. Biologiske Skrifter 5:1-34.

Summerville, K.S., A.C. Bonte and L.C. Fox. 2007. Short-term temporal effects on community structure of Lepidoptera in restored and remnant tallgrass prairie. Restoration Ecology 15:179-188.

Swengel, S.R. 1996. Management responses of three species of declining sparrows in tallgrass prairie. Bird Conservation International 6:241-253.

Taper, M.L., K. Böhning-Gaese and J.H. Brown. 1995. Individualistic responses of birds to environmental change. Oecologia 101:478-486.

Thomas, L.H. 1999. Breeding birds of a large-scale tallgrass prairie restoration in Iowa: Monitoring abundance and frequency of occurrence. MS thesis, Iowa State University.

U.S. Fish and Wildlife Service (USFWS). 1992. Final environmental impact statement. Walnut Creek National Wildlife Refuge master plan. Ft Snelling MN: USFWS.

Van Dyke, F., S.E. Van Kley, C.E. Page and J.G. Van Beek. 2004. Restoration efforts for plant bird communities in tallgrass prairie using prescribed burning and mowing. Restoration Ecology 12: 575-585.

Vickery, P.D., P.L. Tubaro, J.M.C. daSilva, B.G. Peterjohn, J.R. Herkert and R.B. Cavalcanti. 1999. Conservation of grassland birds in the western hemisphere. Pages 2-26 in P.D. Vickery and J.R. Herkert (eds), Ecology and Conservation of Grassland Birds in the Western Hemisphere. Studies in Avian Biology No. 19. Camarillo CA: Cooper Ornithological Society. 
Volkert, W.K. 1992. Response of grassland birds to a large-scale prairie planting project. Passenger Pigeon 54:191-196.

Walk, J.W. and R.E. Warner. 2000. Grassland management for the conservation of songbirds in the Midwestern USA. Biological Conservation 94:165-172.

Wiens, J.A. 1969. An approach to the study of ecological relationships among grassland birds. Ornithological Monographs 8:1-93.

Winter, M., D.H. Johnson and J.A. Shaffer. 2005. Variability in vegetation effects and density and nesting success of grassland birds. Journal of Wildlife Management 69:185-197.

Yamaura, Y., K. Katoh and T. Takahashi. 2006. Reversing habitat loss: Deciduous habitat fragmentation matters to birds in a larch plantation matrix. Ecography 29:827-834.

Zimmerman, J.L. 1971. The territory and density dependent effect in Spiza Americana. Auk 88:591-612.

1988. Breeding season habitat selection by the Henslow's sparrow (Ammodramus henslowii) in Kansas. Wilson Bulletin 100:17-24.

Brian F.M. Olechnowski, Assistant Professor of Natural Science, University of St Francis, 500 Wilcox St, Joliet, IL 60435 , bolech@gmail.com
Diane M. Debinski, Professor of Biology and Conservation Biology, Iowa State University, 253 Bessey Hall, Ames, IA 50011

Pauline Drobney, Director of Research, Neal Smith National Wildlife Refuge, PO Box 399, Prairie City, IA 50228

Karen Viste-Sparkman, Researcher, Neal Smith National Wildlife Refuge, PO Box 399, Prairie City, IA 50228

William T. Reed, Researcher, Iowa State University, 253 Bessey Hall, Ames, IA 50011 